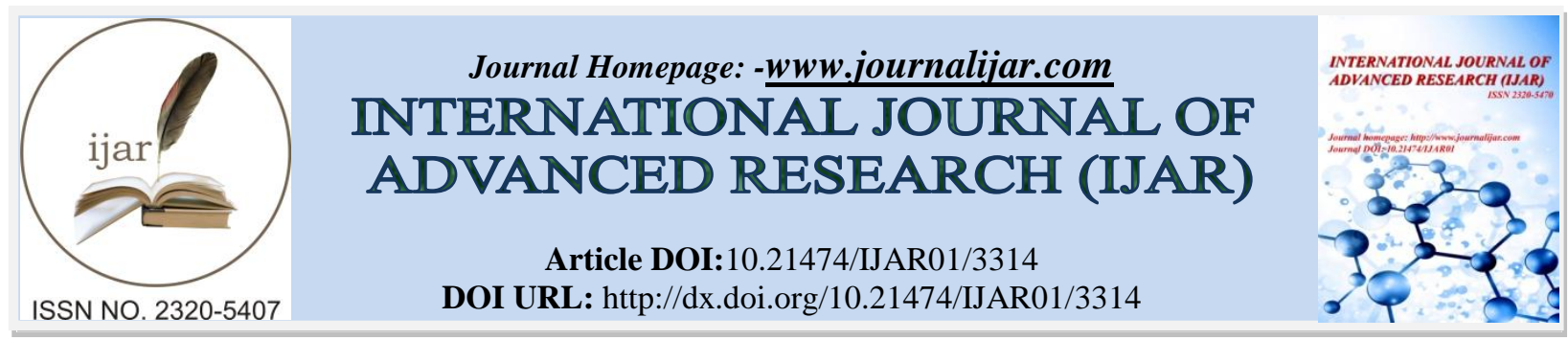

RESEARCH ARTICLE

\title{
PREVALENCE AND FACTORS ASSOCIATED WITH DEPRESSIVE SYMPTOMS AMONG POST- PARTUM MOTHERS IN JEDDAH.
}

\author{
"Dareen H. Alamoudi', Ahmad M.S Almrstani' ${ }^{2}$ Ayman Bukhari², Lujain H. Alamoudi ${ }^{1}$, Amienah M. \\ Alsubaie $^{1}$, Rana K. Alrasheed ${ }^{1}$ and Osama Bajouh ${ }^{2}$. \\ 1. Medical intern - King Abdulaziz University - Jeddah - Saudi arabia. \\ 2. SBOG,ABOG, Assistant Professor-OB/Gyn department, King Abdulaziz University - Jeddah - Saudi Arabia.
}

\section{Manuscript Info}

Manuscript History

Received: 26 December 2016

Final Accepted: 15 January 2017

Published: February 2017

Key words:-

Postpartum depression, risk factors.

\section{Abstract}

Background: Pregnancy and delivery are big events in a woman's life , it could associated with physiological and psychological problems lead to postpartum depression (PPD), This study aimed to assess the prevalence rate of post-partum depression symptom among post-partum mother in Jeddah, Saudi Arabia

Method: This cross sectional study was carried out at five health care centers in Jeddah, Saudi Arabia during the period from January to December 2016, among post-partum mother who admitted to obstetrics \& gynecology units , A semi structure questionnaire was used to collect the data.

Result: A total of 512 postpartum females were included in this study, $(68.8 \%)$ were from group age $25-40 \quad 46.5 \%$ were housewives and $66.6 \%$ had a university education , $65.6 \%$ were from group monthly income more than $8000 \mathrm{SR}, 25.0 \%$ reported medical problem, $43.9 \%$ planned for pregnancy. The EPDS mean score was $12.7 \pm 5.8$ rang $(0-$ $30)$, there was significant association between PPD and the following sociodemographic and medical characteristics ( maternal age, maternal education ,maternal occupation, monthly income , medical problems , planning pregnancy and previous psychological problems).

Conclusion: The current study showed that advanced age, lower educational level for both mother and father, medical problems were risk factors. Further studies need to be conduct to investigate the relation between PPD and other risk factors in Saudi community.

Copy Right, IJAR, 2017,. All rights reserved.

\section{Introduction:-}

Pregnancy and delivery are big events in a woman's life, it is a blessing and joyful experience in normal situation, however the opposite can happen due to the fact that childbirth could associated with physiological and psychological problems lead to postpartum depression (PPD), which is defined as " in the Diagnostic and Statistical Manual for Mental Disorders as major depression with postpartum onset with episodes of depression beginning within 4 weeks of giving birth" . (1) and also as "a non-psychotic depressive state that begins in thepostpartum period, after the child birth, it is a mood disorder that can occur at any time duringthe first year after delivery ". (2)Mental health problem are major public health issue for women in reproductive age in both developing and developed countries ,(2)where several studies reported postpartum depression as the most common 
psychological complications among childbearing women, with prevalence rate between $10-20 \%,(\mathbf{1 , 3 , 4 ) t h i s}$ variety in the prevalence due to several factors : time of survey, population characteristics, culture issues. (1)in the first day after delivery mother will be concentrated on her baby and excited about it but after a few days her mood go down and she may feel sad, depressed and had insomnia that what we called a baby blouse and it begin from the early days after birth to two weeks later and it would may develop to a postpartum depression, $(\mathbf{3 , 5})$. The main characteristics of PPD are: tearfulness, anxiety, emotional stress, guilty feelings , loss of appetite, suicidal thoughts, sleep disoders, concentration and memory problems, exhaustion, and irritability, as well as feelings of weakness and incompetence to deal with the baby. $(\mathbf{1 , 3 , 4 )}$.

the post-partum depression is a relatively common disorders with onset between one and six months after delivery and May last six month or longer, (4)and can affects the health of both the mother ( poor life quality and death) as well as the child (malnutrition, developmental delay, poor growth, and damaged mother-infant relation). (1,3,4,6) There are several risk factors associated with PPD: Familyhistory of previous depressive illness or other psychiatric in the patient or her relatives, life stress , (4) ,labor pain (1)inadequate antenatal care,socio-economic status, (7) chronic illness, caesarian section, (post partum), nutritional deficiency(3),poor social support, (vigod) violence during pregnancy (7), in addition there are few risk factors seen only in developed countries : mutiparity, baby gender and multiplebirths(2,3).

This study aimed to assess the prevalence rate of post-partum depression symptom among post-partum mother in Jeddah , Saudi Arabia and to identify the risk factors associate with PPD in order to help mothers avoiding them.

\section{Method:-}

This cross sectional study was carried out at five health care centers in Jeddah, Saudi Arabia during the period from January to December 2016, among post-partum mother who admitted to obstetrics \& gynecology units, A semi structure questionnaire was used to collect the data from the mothers, where it divided to three parts : first demographic data(age, education level, occupation and monthly income), second pregnancy and delivery characteristics (delivery place, postnatal care service level, delivery mode, planning pregnancy, labor duration, abortion, gravidity and parity, baby health, medical problem during pregnancy, complications, surgical history, depression history, family history) and the third part is the Edinburgh Postnatal Depression Scale which consists of 10 questions with 4 points scale , (8)The data collected was analyzed using SPSS version 20 statistical software. Mean and standard deviations (minimum and maximum) were used to presented parametric data while number (percentage) were used to presented non-parametric data. Comparison for categories variables ( sedation drugs and delirium presentation ) was done using Chi - square test . Statistically significance was considered at the 0.05 level and extreme significant at the 0.0001 level .

\section{Result:-}

A total of 512 postpartum females who completed the demographic , obstetric variables section and the EPDS questionnaire were included in this study. The majority of them (68.8\%) were from group age 25-40 and 19.9\% were less than 25 years, $73.4 \%$ were Saudi. The females who participated in the study included housewives (238, $46.5 \%)$, those employed outside the home $(205,40.0 \%)$, those with a university education or higher $(341,66.6 \%)$, and those who attend high school education $(126,33.6 \%)$. The majority of the participants $(90.8 \%)$ were nonsmokers and (65.6\%) from group monthly income more than 8000 SR, more than two third reported that their husband were employed (68.8\%), with university degree or higher (69.9\%). (Table 1)

Out of the 512 postpartum females $128(25.0 \%)$ reported medical problem, 40 (7.8\%) reported Previous psychological problems and 143 (27.9\%) reported family history of PPD . ( Table 2)

Out of the 512 postpartum females 225 (43.9\%) planned for pregnancy, 190 (37.1\%) reported medical problems during pregnancy, those who had Marital problems numbered 99(68.3\%), those who suffered from depression during last pregnancy at least for one semesters numbered 314 (61.3\%). Out of the 512 postpartum females 368 (71.9\%) delivered in private hospital and $136(26.6 \%)$ delivered in governmental hospital, those who spent Puerperal duration in her family house numbered $215(42 \%)$, most of the female delivered Spontaneously and from them only $93(25.8 \%)$ received epidural analgesia, 407 (79.5\%) reported that baby gender not as they wish, 102 (19.9\%) reported medical problems during delivery and 91 (178\%) had complications after delivery. Half of the 
women $(253-50.4 \%)$ had baby girl $252(49.2 \%)$ had baby boy and $2(0.4 \%)$ had both, only $15(2.9 \%)$ baby reported medical problem, $46.1 \%$ reported both kind of feeding. (Tables 3 ,4\&5)

The EPDS mean score was 12.7 \pm 5.8 rang (0-30) and was divided into two categories with cut off $>13$, of the 512 mothers, $257(50.5 \%)$ had depressive symptoms (EPDS score > 13), and 255 (49.5\%) did not have depres $\neg$ sive symptoms (EPDS scores $\leq 13$ ). (Table 6)

The results showed significant association between PPD and the following sociodemographic and medical characteristics ( maternal age, maternal education , maternal occupation, monthly income , husband occupation and education level, medical problems, baby health, planning pregnancy, Medical problem during pregnancy and delivery, complication and semester depression, family history of PPD and previous psychological problems ) where advanced age, lower level of education, working mother, lower monthly income, husband level of education, working husband, positive medical problems before-during pregnancy and during and after delivery, positive family history of PPD and previous psychological problems and un planning pregnancy showed higher scores in EPDS $(\mathrm{p}=0.02, \mathrm{p}<0.0001, \mathrm{p}<0.0001, \mathrm{p}<0.0001, \mathrm{p}<0.0001, \mathrm{p}<0.0001, \mathrm{p}=0.04, \mathrm{p}=0.03, \mathrm{p}=0.04, \mathrm{p}=0.03, \mathrm{p}=0.04$, $\mathrm{p}=0.01, \mathrm{p}=0.04, \mathrm{p}=0.01$ and $\mathrm{p}=0.006)$ respectively. (Table 7)

\section{Discussion:-}

Several studies were conduct about the prevalence of PPD and the associated risk factors, where PPD had big influence on the baby emotional and social development and this influencecontinue during teenage and adult years. (3,9)In industrial countries there is rapid screening for PPD so an early intervention can be done to decrease the negative effects of PPD on mothers and babies lives.(3,10,11)The current study showed that almost the half ofparticipants mothers $(49.5 \%)$ had depressive symptoms during post-partumperiod. Previous studies in Nepal and Saudi Arabia reported the prevalence of PPD $30-33 \%$ with cut off score $\geq 10,(\mathbf{2}, \mathbf{3})$ also the results from Pakistan and India studies the prevalence was between $11 \%-40 \%$, while in other studies with cut of $\geq 12$ the prevalence was $6 \%-12 \%,(\mathbf{2 , 1 2 , 1 3 )}$ and $15.4 \%$ in Turkish study with cut off $\geq 13,(7)$ this Varity in the prevalence rate could be due to the difference cut off, multi-cultural and multi-social factors, sample size and methods.(2,3,7,12,14,15)

The findings of current study showed that mother aged more than 40 years are more likely to develop PPD than younger mother, similar results were found in Singapore Nepal and Canada studies the authors reported high prevalence of PPD among women aged 35-40,(1,2,16)in contrast in Turkey and Canada studies the authors reported high prevalence of PPD among young mother, $(\mathbf{2 , 7 , 1 7 , 1 8 , 1 9 )}$ while in Saudi Arabia study the association was between older and younger age. (3)

Several studies investigated the association between PPD occurrence and sociodemographic data (mother's education and occupation, monthly income and father's education and occupation),(6,20-26) where the results showed contradictory evidence $\mathbf{( 1 , 2 , 3 , 7 )}$, in Nepal ,Singapore, turkey and Saudi study there was no association between mother's education level, occupation and low monthly income and PPD, (1,2,3,7)while in other studies there was positive association between PPD and mother's lower education, being a housewife, and lower monthly income,(2,3,7 27-32)also in 2007 study the authors reported significant association between lower partner education and occupationand PPD,$(\mathbf{7 , 3 3})$ the current study showed consistent with previous study regarding mother low educational level and controversy result regarding mother occupation and monthly income, where the high prevalence of PPD was between working mothers and high monthly income.

The current study findings showed that any medical problems in any time before or during pregnancy , during or after delivery had a strong effect on developing PPD ( $\mathrm{p}=0.03 \mathrm{p}=0.004, \mathrm{p}=0.03, \mathrm{p}=0.01)$, this consistent with previous studies,(1-7, 34-36) in Saudi Arabia study the authors reported significant association between anemia during pregnancy and $\operatorname{PPD}(3)$, in Singapore study there was significant association between medical problem during pregnancy such as GDM and hypertension and PPD. $(\mathbf{1 , 3 7 , 3 8 )}$

In addition to that the current studies confirmed previous studies findings that stressful life such as family problem , week relation with husband or his family , previous psychological problems specially anxiety, exhausts , pregnancy depression, tearful and lake of sleep, and family history of PPD either first degree relative or second degree relative , (1-7) in Nepal studies the authors reported that there is relation between PPD and early contractions during pregnancy andmaternity blues after seven days from delivery, $(\mathbf{2 , 3 9 )}$ in Turkey study the authors confirmed the relation between PPD and antepartum depressive symptoms which assessed byHADS-D, and they reported that thinking in committing suicidal during pregnancy is a high risk factors in developing PPD (odds ratio 6.99,CI 2.08- 
23.49), (7,40,41) similar results were found in Singapore study where the authors reported high prevalence of PPD among women with previous psychological problems. $(\mathbf{1 , 3 7 , 3 8 )}$

Regarding planning pregnancy and baby gender, the results of the current study showed significant association between developing PPD and unplanned pregnancy ( $\mathrm{p}=0.01)$, this consistent with Turkey study . (7)

Pain during delivery considered as the most severe pain could be experience by some women during their entire life , it is not life-threatening, however it has association with the risk of development post-traumatic stress disorder, mode disorders, weakness of cognitive function and causing post-partum depression. Epidural analgesia was addressed in several studies as an effective way to reduce delivery pain and decreasing the incidence rate of PPD on the Edinburgh Postnatal Depression Scale (EPDS). The new guidelines recommended to use epidural analgesia when mothers ask if there is no medical contraindication, this use affected by several factors such as labor progress, mother condition and preferring. $(\mathbf{1}, \mathbf{4 2}-44)$ In Singapore study the authors reported significant association between the using of epidural analgesia and decreasing the score of Edinburgh Postnatal Depression Scale $(P=0.0078)$,(1)similar result was found in Hiltunen et al study (odds ratio [OR] 0.25, 95\% confidence interval [CI] 0.09-0.72), (45)and Ding T et al study (OR 0.32, 95\% CI, $0.11-0.89, P=0.029),(43)$ although the current study couldn't establish this relation.

There was no significant difference in the prevalence rate of PPD regarding mode of delivery, smoking and baby gender wishing .

Table (1):-Demographic data:

\begin{tabular}{|c|c|c|}
\hline Variables & $\mathrm{N}$ & $\%$ \\
\hline \multicolumn{3}{|l|}{ Age } \\
\hline Less than 25 & 102 & 19.9 \\
\hline $25-40$ & 342 & 66.8 \\
\hline More than 40 & 68 & 13.3 \\
\hline \multicolumn{3}{|l|}{ nationality } \\
\hline Saudi & 376 & 73.4 \\
\hline Non Saudi & 136 & 26.6 \\
\hline \multicolumn{3}{|l|}{ Education level } \\
\hline Postgraduate & 34 & 6.6 \\
\hline University degree & 307 & 60.0 \\
\hline High school & 126 & 33.6 \\
\hline Intermediate & 29 & 5.7 \\
\hline Elementary or lower & 16 & 3.1 \\
\hline \multicolumn{3}{|l|}{ Occupation } \\
\hline Student & 69 & 13.5 \\
\hline Employee & 205 & 40.0 \\
\hline House wife & 238 & 46.5 \\
\hline \multicolumn{3}{|l|}{ Smoking } \\
\hline Yes & 47 & 9.2 \\
\hline No & 465 & 90.8 \\
\hline \multicolumn{3}{|l|}{ Monthly income } \\
\hline Less than 5000 & 62 & 12.1 \\
\hline $5000-8000$ & 114 & 22.3 \\
\hline More than 8000 & 336 & 65.6 \\
\hline \multicolumn{3}{|l|}{ Husband occupation } \\
\hline Employee & 352 & 68.8 \\
\hline Business man & 134 & 26.1 \\
\hline Retired & 26 & 5.1 \\
\hline \multicolumn{3}{|l|}{ Husband education level } \\
\hline University degree & 336 & 65.6 \\
\hline Postgraduate & 22 & 4.3 \\
\hline High school & 109 & 21.3 \\
\hline Intermediate & 29 & 5.7 \\
\hline Elementary or lower & 16 & 3.1 \\
\hline Variables & Mean \pm SD & Rang (Min-Max) \\
\hline Family members number & $5.0 \pm 2.0$ & $(3.0-9.0)$ \\
\hline
\end{tabular}


Table (2):-Medical characteristics obstetrics (pregnancy and delivery) characteristics

\begin{tabular}{|l|l|l|}
\hline Variables & N & $\%$ \\
\hline Medical problems & 128 & 25.0 \\
\hline Yes & 385 & 75.0 \\
\hline No & & \\
\hline Specify & 21 & 16.4 \\
\hline Diabetes & 27 & 21.1 \\
\hline Hypertension & 28 & 21.9 \\
\hline Hypothyroidism & 4 & 3.1 \\
\hline Anemia & 48 & 37.5 \\
\hline Others & \multicolumn{2}{|l|}{} \\
\hline Family history of PPD & 143 & 27.9 \\
\hline Yes & 369 & 72.1 \\
\hline No & \multicolumn{2}{|l|}{} \\
\hline Who & 76 & 51.4 \\
\hline Sister & 47 & 20.4 \\
\hline Mother & 20 & 28.2 \\
\hline Aunt & \multicolumn{2}{|l|}{} \\
\hline Previous psychological problems & 40 & 7.8 \\
\hline Yes & 472 & 92.2 \\
\hline No & \multicolumn{2}{|l|}{} \\
\hline Specify & 10 & 25 \\
\hline Depression & 1 & 2.5 \\
\hline Tearful & 2 & 5 \\
\hline Anxiety and uncomfortable & 27 & 67.5 \\
\hline Un mention & \multicolumn{2}{|l|}{} \\
\hline
\end{tabular}

Table (3):-Obstetrics (pregnancy) characteristics

\begin{tabular}{|c|c|c|}
\hline Variables & $\mathrm{N}$ & $\%$ \\
\hline \multicolumn{3}{|l|}{ Prenatal care level } \\
\hline Excellent & 166 & 32.4 \\
\hline Very good & 184 & 36.0 \\
\hline Good & 99 & 19.3 \\
\hline Average & 52 & 10.2 \\
\hline Poor & 11 & 2.1 \\
\hline \multicolumn{3}{|l|}{ Planning pregnancy } \\
\hline Yes & 225 & 43.9 \\
\hline No & 276 & 53.9 \\
\hline Un mention & 11 & 2.1 \\
\hline \multicolumn{3}{|c|}{ Medical problems during last pregnancy } \\
\hline Yes & 190 & 37.1 \\
\hline No & 322 & 62.9 \\
\hline \multicolumn{3}{|l|}{ Personal problems } \\
\hline Marital problems & 99 & 68.3 \\
\hline Traffic accidents & 12 & 8.2 \\
\hline Losing family member & 34 & 23.5 \\
\hline \multicolumn{3}{|c|}{ Depression during current pregnancy } \\
\hline First semester & 172 & 33.5 \\
\hline Second semester & 63 & 12.3 \\
\hline Third semester & 64 & 12.5 \\
\hline Two semesters & 9 & 1.8 \\
\hline All semesters & 6 & 1.2 \\
\hline No & 198 & 38.7 \\
\hline Variables & Median & quartile (25-75) \\
\hline Gravidity & 2.0 & $0.0-4.0$ \\
\hline Abortion & 1.0 & $0.0-2.0$ \\
\hline
\end{tabular}


Table (4):-Obstetrics (delivery) characteristics

\begin{tabular}{|c|c|c|}
\hline Variables & $\mathrm{N}$ & $\%$ \\
\hline \multicolumn{3}{|l|}{ Birth place } \\
\hline Governmental hospital & 136 & 26.6 \\
\hline Private hospital & 368 & 71.9 \\
\hline Polyclinics & 4 & .8 \\
\hline Home & 4 & .8 \\
\hline \multicolumn{3}{|l|}{ Puerperal duration place } \\
\hline My home & 215 & 42.0 \\
\hline My husband family house & 21 & 4.1 \\
\hline My family house & 276 & 53.9 \\
\hline \multicolumn{3}{|l|}{ Postnatal care level } \\
\hline Excellent & 154 & 30.1 \\
\hline Very good & 181 & 35.4 \\
\hline Good & 110 & 21.5 \\
\hline Average & 53 & 10.2 \\
\hline Poor & 14 & 2.8 \\
\hline \multicolumn{3}{|l|}{ Delivery mode } \\
\hline Spontaneous & 360 & 70.3 \\
\hline Cesarean & 152 & 29.7 \\
\hline \multicolumn{3}{|l|}{ Epidural } \\
\hline Yes & 93 & 25.8 \\
\hline No & 267 & 74.2 \\
\hline \multicolumn{3}{|c|}{ Gender baby did not consistent with the wishes of the family or you } \\
\hline Yes & 95 & 18.6 \\
\hline No & 407 & 79.5 \\
\hline Un mention & 10 & 2.0 \\
\hline \multicolumn{3}{|c|}{ Medical problems during last delivery } \\
\hline Yes & 102 & 19.9 \\
\hline No & 410 & 80.1 \\
\hline \multicolumn{3}{|c|}{ Complication after last delivery } \\
\hline Yes & 91 & 17.8 \\
\hline No & 420 & 82.0 \\
\hline \multicolumn{3}{|l|}{ Surgical history } \\
\hline Yes & 41 & 8.0 \\
\hline No & 471 & 92.0 \\
\hline Variables & Median & quartile $(25-75)$ \\
\hline Labor duration & 5.0 & $2.0-11.0$ \\
\hline \multicolumn{3}{|c|}{ Table (5):-Neonatal section } \\
\hline Variables & $\mathrm{N}$ & $\%$ \\
\hline \multicolumn{3}{|l|}{ Baby gender } \\
\hline Boy & 252 & 49.2 \\
\hline Girl & 253 & 50.4 \\
\hline Both & 2 & .4 \\
\hline \multicolumn{3}{|l|}{ Baby health } \\
\hline Healthy & 497 & 97.1 \\
\hline Sick & 15 & 2.9 \\
\hline \multicolumn{3}{|l|}{ Specify } \\
\hline Jaundice & 2 & 14.3 \\
\hline Congenital anomalies & 6 & 42.7 \\
\hline Others & 7 & 43.0 \\
\hline \multicolumn{3}{|l|}{ Feeding } \\
\hline Breastfeeding & 186 & 36.3 \\
\hline Bottle & 90 & 17.6 \\
\hline Both & 236 & 46.1 \\
\hline
\end{tabular}


Table (6):-EDP scale:

\begin{tabular}{|l|l|l|}
\hline Variables & Mean \pm SD & Rang (Min-Max) \\
\hline *I have been able to laugh and see the funny side of things & $1.0 \pm 0.8$ & $(0-3)$ \\
\hline *I have looked forward with enjoyment to things & $1.0 \pm 0.8$ & $(0-3)$ \\
\hline $\begin{array}{l}\text { I have blamed myself unnecessarily when things went } \\
\text { wrong }\end{array}$ & $1.6 \pm 0.9$ & $(0-3)$ \\
\hline *I have been anxious or worried for no good reason & $1.5 \pm 0.9$ & $(0-3)$ \\
\hline have felt scared or panicky for no very good reason & $1.5 \pm 0.9$ & $(0-3)$ \\
\hline Things have been getting on top of me & $1.8 \pm 0.9$ & $(0-3)$ \\
\hline I have been so unhappy that I have had difficulty sleeping & $1.7 \pm 1.0$ & $(0-3)$ \\
\hline I have felt sad or miserable & $1.3 \pm 1.0$ & $(0-3)$ \\
\hline I have been so unhappy that I have been crying & $1.3 \pm 1.0$ & $(0-3)$ \\
\hline The thought of harming myself has occurred to me & $1.0 \pm 0.7$ & $(0-3)$ \\
\hline Total & $12.7 \pm 5.8$ & $(0-30)$ \\
\hline
\end{tabular}

Table (7):-The relation between PPD and demographic data and medical characteristics:

\begin{tabular}{|c|c|c|c|c|c|}
\hline \multicolumn{2}{|l|}{ Variables } & Mean & \pm & SD & $\mathrm{P}$ value \\
\hline \multirow[t]{3}{*}{ Age } & Less than 25 & 11.71 & \pm & 6.29 & \multirow[t]{3}{*}{$0.02 *$} \\
\hline & $25-40$ & 12.76 & \pm & 5.69 & \\
\hline & More than 40 & 13.91 & \pm & 5.50 & \\
\hline \multirow[t]{5}{*}{ Education level } & Postgraduate & 12.64 & \pm & 5.63 & \multirow[t]{5}{*}{$0.0001^{*}$} \\
\hline & University degree & 12.83 & \pm & 5.98 & \\
\hline & High school & 14.00 & \pm & 5.38 & \\
\hline & Intermediate & 9.89 & \pm & 5.32 & \\
\hline & Elementary or lower & 14.81 & \pm & 4.44 & \\
\hline \multirow{3}{*}{ Occupation } & Student & 14.52 & \pm & 4.16 & \multirow[t]{3}{*}{$0.0001 *$} \\
\hline & \begin{tabular}{|l|} 
Employee \\
\end{tabular} & 13.260 & \pm & 5.46 & \\
\hline & House wife & 11.70 & \pm & 6.29 & \\
\hline \multirow[t]{3}{*}{ Monthly income } & Less than 5000 & 9.85 & \pm & 7.52 & \multirow[t]{3}{*}{$0.0001^{*}$} \\
\hline & \begin{tabular}{|l|}
$5000-8000$ \\
\end{tabular} & 11.76 & \pm & 5.78 & \\
\hline & More than 8000 & 13.56 & \pm & 5.23 & \\
\hline \multirow[t]{5}{*}{ Husband educational level } & University degree & 13.06 & \pm & 5.39 & \multirow[t]{5}{*}{$0.0001^{*}$} \\
\hline & Postgraduate & 14.09 & \pm & 5.07 & \\
\hline & High school & 11.86 & \pm & 6.41 & \\
\hline & Intermediate & 9.31 & \pm & 6.00 & \\
\hline & Elementary or lower & 9.56 & \pm & 7.30 & \\
\hline \multirow[t]{3}{*}{ Husband occupation } & \begin{tabular}{|l|} 
Employee \\
\end{tabular} & 13.14 & \pm & 5.40 & \multirow[t]{3}{*}{$0.04 *$} \\
\hline & Business man & 11.17 & \pm & 6.23 & \\
\hline & Retired & 11.95 & \pm & 7.64 & \\
\hline \multirow{2}{*}{ Medical problem } & Yes & 13.67 & \pm & 5.18 & \multirow{2}{*}{$0.03 *$} \\
\hline & No & 12.35 & \pm & 5.97 & \\
\hline \multirow{2}{*}{$\begin{array}{ll}\begin{array}{l}\text { Medical problem during } \\
\text { pregnancy }\end{array} & \\
\end{array}$} & Yes & 13.68 & \pm & 5.02 & \multirow[t]{2}{*}{$0.004^{*}$} \\
\hline & No & 12.15 & \pm & 6.16 & \\
\hline \multirow{2}{*}{$\begin{array}{lll}\begin{array}{l}\text { Medical problem } \\
\text { delivery }\end{array} & \text { during } \\
\end{array}$} & Yes & 13.93 & \pm & 5.32 & \multirow[t]{2}{*}{$0.03^{*}$} \\
\hline & No & 12.43 & \pm & 6.06 & \\
\hline \multirow{2}{*}{ Complications } & Yes & 14.13 & \pm & 5.03 & \multirow{2}{*}{$0.01 *$} \\
\hline & No & 12.41 & \pm & 5.92 & \\
\hline \multirow[t]{2}{*}{ Baby health } & Healthy & 12.61 & \pm & 5.82 & \multirow[t]{2}{*}{$0.04 *$} \\
\hline & Sick & 15.66 & \pm & 5.40 & \\
\hline \multirow[t]{2}{*}{ Planning pregnancy } & Yes & 12.00 & \pm & 5.87 & \multirow[t]{2}{*}{$0.01 *$} \\
\hline & No & 13.32 & \pm & 5.77 & \\
\hline \multirow[t]{4}{*}{ Family history of PPD } & Yes & 13.89 & \pm & 5.16 & $0.004 *$ \\
\hline & No & 12.24 & \pm & 6.00 & \\
\hline & Yes & 15.10 & \pm & 4.41 & $0.006^{*}$ \\
\hline & No & 12.48 & \pm & 5.88 & \\
\hline Semester depression & $1^{\mathrm{st}}$ & 14.63 & \pm & 5.10 & $0.03 *$ \\
\hline & $2^{\text {nd }}$ & 13.96 & \pm & 4.52 & \\
\hline
\end{tabular}




\begin{tabular}{|l|l|l|l|}
$3^{\text {rd }}$ & 13.84 & \pm & 4.52 \\
\hline $1^{\text {st }} \& 2^{\text {nd }}$ & 18.66 & \pm & 5.00 \\
\hline $2^{\text {nd }} \& 3^{\text {rd }}$ & 6.50 & \pm & 4.19 \\
\hline All & 17.16 & \pm & 4.57 \\
\hline
\end{tabular}

\section{Conclusion:-}

This study highlighted the high prevalence rate of PPD symptoms. Whenever the early detection of the risk factors for PPD , the easier for the doctor to intervene to treat and remedy it and prevent it from getting worse .The current study showed that advanced age, lower educational level for both mother and father were risk factors , however there are many other risk factors couldn't be detect in the current study. Further studies need to be conduct to investigate the relation between PPD and other risk factors in Saudi community, more awarenesscamping need to be held to raise the awareness about PPD among mothers and community, also psychiatrist and social worker should attend a postnatal care unit on a regular base to talk with mothers, advise them and help them in facing their fear .

\section{Acknowledgment:-}

The Authors would like to acknowledge the following medical interns (Elaf A. Bahanshel, Alhanouf B. Alqarni, Rahaf T. Eskandrani, Sara O Amro, RenadH.Ateeq, Ohoud M Baajlan, Hala MA Kanawi , Rana M Jubran, Esraa A Alzahrani and Leena E Azhar) for their efforts in collecting the data.

\section{References:-}

1. Suhitharan T1, Pham TP2, Chen H3, Assam PN4, Sultana R2, Han NL5, Tan EC6, Sng BL Investigating analgesic and psychological factors associated with risk of postpartum depression development: a case-control study. Neuropsychiatr Dis Treat. 2016 Jun 9;12:1333-9.

2. Giri RK1, Khatri RB2, Mishra SR3, Khanal V4, Sharma VD5, Gartoula RP. Prevalence and factors associated with depressive symptoms among post-partum mothers in Nepal. BMC Res Notes. 2015 Mar 31;8:111.

3. Alharbi AA1, Abdulghani HM. Risk factors associated with postpartum depression in the Saudi population. Neuropsychiatr Dis Treat. 2014 Feb 17;10:311-6.

4. Villegas L1, McKay K, Dennis CL, Ross LE. Postpartum depression among rural women from developed and developing countries: a systematic review. J Rural Health. 2011 Summer;27(3):278-88.

5. Postnatal Depression Information Booklet. 2008. Postnatal Depression Support Group.www.pnd.ie

6. Vigod S, Villegas L, Dennis C-L, Ross L. Prevalence and risk factors for postpartum depression among women with preterm and low-birth-weight infants: a systematic review. BJOG 2010;117:540-550.

7. Turkcapar AF1, Kadığlu N2, Aslan E3, Tunc S4, Zayıfoğlu M5, Mollamahmutoğlu L. Sociodemographic and clinical features of postpartum depression among Turkish women: a prospective study. BMC Pregnancy Childbirth. 2015 May 3;15:108.

8. Cox, J.L., Holden, J.M., and Sagovsky, R. 1987. Detection of postnatal depression: Development of the 10-item Edinburgh Postnatal Depression Scale. British Journal of Psychiatry 150:782-786.

9. Markhus MW, Skotheim S, Graff IE, et al. Low omega-3 index in pregnancy is a possible biological risk factor for postpartum depression. PLoS One. 2013;8(7):e67617.

10. 33. Davies BR, Howells S, Jenkins M. Early detection and treatment of postnatal depression in primary care. J AdvNurs. 2003;44(3): 248-255.

11. Zauderer C. Postpartum depression: how childbirth educators can help break the silence. J Perinat Educ. 2009;18(2):23-31.

12. Regmi S, Sligl W, Carter D, Grut W, Seear M. A controlled study of postpartum depression among Nepalese women: validation of the Edinburgh Postpartum Depression Scale in Kathmandu. Trop Med Int Health. 2002;7(4):378-82.

13. Nepal M, Sharma V, Koirala N, Khalid A, Shresta P. Validation of the Nepalese version of Edinburgh Postnatal Depression Scale in tertiary health care facilities in Nepal. Nep J Psychiatry. 1999;1:46-50.

14. DÃ̃ RheimHoâ€ Yen S, TschudiBondevik G, Eberhardâ€ Gran M, Bjorvatn BR. Factors associated with depressive symptoms among postnatal women in Nepal. ActaObstetGynecol Scand. 2007;86(3):291-7.

15. Halbreich U, Karkun S. Cross-cultural and social diversity of prevalence of postpartum depression and depressive symptoms. J Affect Disord. 2006;91(2-3):97-111.

16. Muraca GM, Joseph KS. The association between maternal age and depression. J ObstetGynaecol Can. 2014;36(9):803-810.

17. Daoud N, Shoham-Vardi I, Urquia ML, O’Campo P. Polygamy and poor mental health among Arab Bedouin women: do socioeconomic position and social support matter? Ethn Health. Epub May 30, 2013.

18. Shepard LD. The impact of polygamy on women's mental health: a systematic review. EpidemiolPsychiatr Sci. 2013;(1):47-62. 
19. Goshtasebi A, Alizadeh M, Gandevani SB. Association between maternal anaemia and postpartum depression in an urban sample of pregnant women in Iran. J Health PopulNutr. 2013;31(3):398-402.

20. Black MM, Baqui AH, Zaman K, et al. Depressive symptoms among rural Bangladeshi mothers: implications for infant development. J Child Psychol Psychiatry. 2007;48(8):764-772.

21. Ege E, Timur S, Zincir H, Geckil E, Sunar-Reeder B. Social support and symptoms of postpartum depression among new mothers in Eastern Turkey. J ObstetGynaecol Res. 2008;34(4):585-593.

22. Kheirabadi GR, Maracy MR, Barekatain M, Salehi M, Sadri GH, Kelishadi M, Cassy P. Risk factors of postpartum depression in rural areas of Isfahan Province, Iran. Arch Iran Med. 2009;12(5):461-467.

23. Savarimuthu RJ, Ezhilarasu P, Charles H, Antonisamy B, Kurian S, Jacob KS. Post-partum depression in the community: a qualitative study from rural South India. Int J Soc Psychiatry. 2010 56(1):94-102.

24. Stewart RC, Bunn J, Vokhiwa M, et al. Common mental disorder and associated factors amongst women with young infants in rural Malawi. Soc Psychiatry PsychiatrEpidemiol. 2009;45(5):551-559.

25. Chaaya M, Campbell OM, El Kak F, Shaar D, Harb H, Kaddour A. Postpartum depression: prevalence and determinants in Lebanon. Arch WomensMent Health. 2002;5(2):65-72.

26. Chandran M, Tharyan P, Muliyil J, Abraham S. Post-partum depression in a cohort of women from a rural area of Tamil Nadu, India. Incidence and risk factors. Br J Psychiatry. 2002;181:499-504.

27. Clarke K, Saville N, Shrestha B, Costello A, King M, Manandhar D, et al. Predictors of psychological distress among postnatal mothers in rural Nepal: a cross-sectional community-based study. J Affect Disord. 2014;156:76-86.

28. O'hara MW, Swain AM. Rates and risk of postpartum depression-a meta-analysis. Int Rev Psychiatry. 1996;8(1):3754.

29. Lee DT, Yip AS, Leung TY, Chung TK. Identifying women at risk of postnatal depression: prospective longitudinal study. Hong Kong Med J. 2000;6(4):349-354.

30. Goker A, Yanikkerem E, Demet MM, Dikayak S, Yildirim Y, Koyuncu FM. Postpartum depression: is mode of delivery a risk factor? ISRN Obstet Gynecol. 2012;2012:616759.

31. Saleh El-S, El-Bahei W, El-Hadidy MA, Zayed A. Predictors of postpartum depression in a sample of Egyptian women. Neuro Psychiatr Dis Treat. 2013;9:15-24.

32. Segre LS, O'Hara MW, Arndt S, Stuart S. The prevalence of postpartum depression: the relative significance of three social status indices. Soc Psychiatry PsychiatrEpidemiol. 2007;42:316-21.

33. Da-Silva V.A., Moraes-Santos A.R., Carvalho M.S., Martins M.L.P., Teixeira N.A.. Prenatal and postnatal depression among low income Brazilian women. Braz J Med Biol Res [serial on the Internet]. 1998 June [cited 2014 Jan 05]; 31: 799-804. Available from: http://www.scielo.br/scielo.php?script=sci_arttext\&pid=S0100879X1998000600012\&lng=en. http://dx.doi.org/10.1590/ S0100-879X1998000600012.

34. Ross LE, , Dennis CL.. The prevalence of postpartum depression among women with substance use, an abuse history, or chronic illness: a systematic review.J Womens Health (Larchmt). 2009 Apr;18(4):475-86.

35. Chaaya M, Campbell OM, El Kak F, Shaar D, Harb H, Kaddour A. Postpartum depression: Prevalence and determinants in Lebanon. Arch WomensMent Health 2002;5: 65-72.

36. Fo“ rger F, Ostensen M, Schumacher A, Villiger PM. Impact of pregnancy on health-related quality of life evaluated prospectively in pregnant women with rheumatic diseases by the SF-36 health survey. Ann Rheum Dis 2005;64:1494-1499.

37. Robertson E, Grace S, Wallington T, Stewart DE. Antenatal risk factors for postpartum depression: a synthesis of recent literature. Gen Hosp Psychiatry. 2004;26(4):289-295.

38. Chee CY, Chong YS, Ng TP, Lee DT, Tan LK, Fones CS. The association between maternal depression and frequent non-routine visits to the infant's doctor - a cohort study. J Affect Disord. 2008;107(1-3): 247-253.

39. Gonidakis F, Rabavilas AD, Varsou E, Kreatsas G, Christodoulou GN. A 6-month study of postpartum depression and related factors in Athens Greece. Compr Psychiatry. 2008;49(3):275-82.

40. O’Hara MW. Postpartum depression: what we know. J Clin Psychol. 2009;65:1258-69. 36. Orsel S, Karadag H, Turkcapar H, Kahilogullari AK. Diagnosis and classification

41. subtyping of depressive disorders: comparison of three methods. Bull ClinPsychopharmacol. 2010;20:57-65.

42. Silva M and Halpern SH. Epidural Analgesia for Labor and Delivery. Local RegAnesth. 2010; 3: $143-153$.

43. Ding T, Wang DX, Qu Y, Chen Q, Zhu SN. Epidural Labor Analgesia Is Associated witha Decreased Risk of Postpartum Depression: A Prospective Cohort Study. AnesthAnalg. 2014 Aug;119(2):383-92.

44. Sng BL, LeongWL, Zeng Y, Siddiqui FJ, AssamPN, LimY, Chan ESY, Sia AT. Early versus late initiation of epidural analgesia for labour (Review). Cochrane Database of Systematic Reviews 2014, Issue 10. Art. No.: CD007238. DOI: 10.1002/14651858.CD007238.pub2.

45. Hiltunen P, Raudaskoski T, Ebeling H, Moilanen I. Does pain relief during delivery decrease the risk of postnatal depression? ActaObstetGynecol Scand. 2004;83(3):257-261. 